\title{
Discussing the Effect of Medical Team Model in the Hospice Palliative Care to Terminal Cancer Patient
}

\author{
Yin Han Lu and Chia Hsing Wu* \\ Department of Family Medicine, National Yang Ming University Hospital, Taiwan
}

*Corresponding author: Chia Hsing Wu, Department of Nursing, Cardinal Tien Junior College of Healthcare and management, New Taipei city, Taiwan

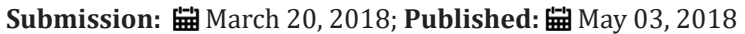

\section{Introduction}

One of the main purposes of the hospice-palliative care program is to provide a hospice for the terminally ill cancer patients. Weisman assumed that a hospice should consist of five aspects which include Awareness of the end of life, Acceptance, Proprietary, Timing and Comfort. Therefore, the purpose of this research is to explore firstly the condition of the terminal cancer patients in the hospice. Secondly to Investigate the effect of Medical team work method and finally to compare the relationship between the hospice score and service result [1].

\section{Materials}

This study involved subjects from those from the terminally ill cancer patients who passed away in the hospice palliative care unit at medical Centre during 2012-2013. There were a total of 292patients considered for the study [2]. Thirty patients were excluded from the study because there was data missing from their file. The remaining 262 patients information was collected on 157 males (53.8\%) and 105 females (36\%).

\section{Methodology}

The method used was Snowball sampling with questionnaires combined with Qualitative analysis to achieve the target of this study [3-6]. It was divided into two parts the "hospice indicators" and "hospice service evaluation". The assessment was carried during the medical team work meeting once a week. The team work members involved were the Hospice Physician, Nurses, Psychologists, and Clergy, Social workers, Art therapists and other counsellors [7].

The purpose of the Case discussion was to evaluate the "hospice indicators" and "hospice service evaluation" of the patients who died during the week in the unit. If there was any controversy in the opinions, the views of primary care would be given priority [8]. Firstly, the assessment of "hospice indicators" referred to in Weisman's hospice five symptoms is used as the assessment criteria. Scores were in settings from 0-3. It was given on the day of patient's admission, and also on the three day before the patient passed away. Secondly, the "hospice service evaluation "consisted of six aspects with twelve indicators. It can be used to assess either patients or families regarding to the work of the medical team [912].

\section{Result}

The results show that there was a dramatic increase on every item of "hospice indicators", although "comfort" showed the most significant increase $(2.57 \pm 0.56$ vs $1.90 \pm 0.67, \mathrm{p}<0.05)$ after the hospice palliative care score was applied [13]. With the "hospice service evaluation", scores could reach to up to 4 which was dramatically associated to the "hospice indicators $(\mathrm{p}<0.05)$.

\section{Conclusion}

To sum up, caring of terminally ill cancer patients through hospice-palliative care medical team method showed that the "hospice indicator" for the terminal cancer patients were markedly increased on all aspects. Those aspects with high scores included the following sections of "family's grief support", "patient participation" and "non-verbal conversation support". It indicated that the medical team members were able to demonstrate complete respect for the treatment decision making and patient rights, while also providing adequate grief advice for the families [12]. However, a lower score was given in the "emotion stability" which showed that psychological support should be a focus for further study in the future [14].

\section{References}

1. Aries P (1974) Western Attitudes Toward Death. John Hopkins University Press, Baltimore, USA.

2. Aries P (1981) The hour of Our Death. Allen Lane, London.

3. Doyle D, zhanks G, Macdonald N (1994) Oxford Textbook of palliative Medcine. Oxford University Press, New York, USA.

4. Field D (1989) Nursing the Dying. Taristock/Routledge, London.

5. Glaser BG, Strauss AL (1965) Awareness of Dying Aldine, New York, USA.

6. Glaser BG, Strauss AL (1968) Time for Dying Aldine, Chicago, USA. 
7. Glaser BG, Strauss AL (1971) Strauss Passage. Routledge and Kegan panl, London.

8. Kellehear A (1990) Dying of cancer: The Final year of Life. Harwood Academic Publishers, Melbourne, USA

9. Kelner MJ, Bourgeault IL (1993) Patients control over dying: response of health care. Professionals Soc Sci Med 36(6): 757-765.

10. Kubler Ross E (1969) On Death and Dying New York, USA.

11. Metcal P, Huntington R (1991) Celebrations of Death: The Anthropology of Mortuary Ritual, Cambridge University Press, Cambridge, USA.
12. Nimocks MJA, Webb L, Connell JR (1987) Communication and terminally ill: a theoretical model. Death Stud 11(5): 323.

13. Riley JW (1983) Dying and the meanings of death: Sociological inquiries. A Rev Social 9: 191.

14. Wallston KA, Burger C, Smith RA, Baugher RJ (1988) Comparing the quality of death for hospice and non-hospice cancer patients. Med care 26(2): 177-182.

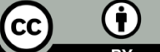

Creative Commons Attribution 4.0 International License

For possible submissions Click Here
Submit Article

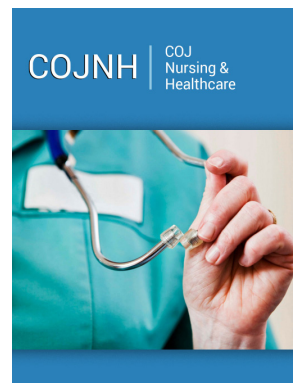

\section{COJ Nursing \& Healthcare}

\section{Benefits of Publishing with us}

- High-level peer review and editorial services

- Freely accessible online immediately upon publication

- Authors retain the copyright to their work

- Licensing it under a Creative Commons license

- Visibility through different online platforms 